\title{
軽合金サツシについて
}

\section{ALLOY FOR ALUMINUM WINDOWS}

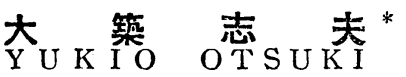

\begin{abstract}
Aluminum windows are gradually becoming popular in this country. However, majority of our architects and building engineers have little knowledge about aluminum alloys. Some complain about aluminum because it is too soft while some complain about its corrosiveness. The former used $2 \mathrm{~S}$ where the material shoud have been harder while the latter used duralumin series when the anti-corrosive nature was important. They all disliked aluminum ever since.

Therefore, all dealers and makers must be extremely careful about the window materials especially at the presentstage when the aluminum windows are becoming popular so that the builders are supplied with correct materials at the reasonable price and eliminate all possible complaints due to the misuse of the material. The important features for the window material may be summarized in four following items :

1. Non-corrosiveness

2. Hardness

3. High yield stress

4. Productivity

(1) and (4) are self-explanetory. Hardness is important because such material cannot be sci ried easily. Lastly, high yield stress is important in two folds. It prevents the window parts from casual deformations. It also saves the material consumption, hence cuts down the window cost.

Up to the present. there are few aluminum windows reported to have been installed. Materials were 23, 33, or SA3, all extruded. All of these materials are non-heat-treatable. Hardness and yield stress of extruded sections of these materials are very small as conpared with those of 63S-T5, the heat-treatable aluminum alloy. At present, 63S-T5 or 63S-T6, seems to be tire only alloy which satisfies all of the above mentioned requirements for sash sections. The writer's study on catalogues of the United States, for instance, Sweet's File, also indicates rixis. More than $60 \%$ of aluminum window suppliers adopt 633-T5.
\end{abstract}

軽合金はその柔か、味のある光沢と、耐猞性があるため

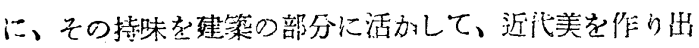

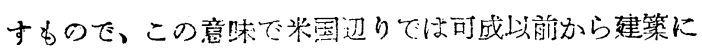

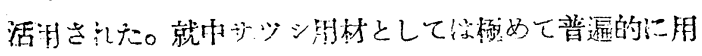
いられて梁た。

吾国では終戦迄よ、アルミニウムは砝ど航空淁に独占 され、建築界には手が出なかつた為に、建策家には照染 がうすく、徒つて若干゙の裝邻朋以外には硝ど月いられな かつた。しかし、終敞後は海外のこうした風潮に刺战さ れ、吾国でも屋根材、サツシとして优はれようとする傾 向にある。

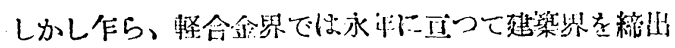

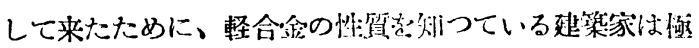
めて少く、「ナルミ」なる言琴は建築婴では柽合金の総你
であり、従つて建勧屋には之以上の笑込んだ分類はなし 得工いのか瓷らざる現状である。徒つて、用途応じて

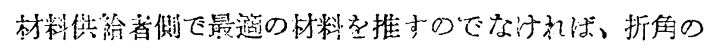

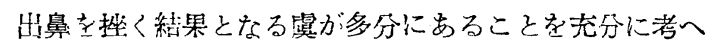
てかからねばならないて考へる。

在来、吾国で 2,3 似はれたアルミサッシは、設計者の 発裴によれば、2S、3S 自至はS A3 の如き非聲处理材 の押出型材が主体の䈋であり、之等の材料は何れる区延 朴では相当の硬さを有するけれどす、押出のままでは柔 かくて、在来の所謂「アルミルに対する通有概念の「腰が

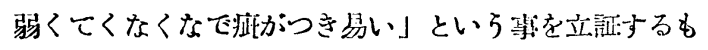
のに外ならず、その結果「やニばり日成ではアルミは歌 日だ」とい5碀たなる可能性が $95 \%$ 侫あると思はれ

* 清水建設株式会犃研究部

The Shimizu Construction Co., Ltd. 
る。

從つて非薙近理材ならば、ストレツチヤー等で相当の 扣工度をむたえて硬化するか、或は又押出易い薙知理材 を朋いて、降伏点と硬度の高い、且耐蝕性のよい材料で なければ、サッシ材料としては不问きであろうと考へ、 鬼に角、少進国である米国で主用されている枌料を調查 してみた。

資料は Sweet File にのせられた 22 種の型錄によつ たが、笑に 15 種は63S であり、その中 10 種ははつき りと63S-T5 としてあることが判明し、予想通り砝ど 大部分か䓡処理材を用いている事がわかつた。

何故？㰬論これは「アルミ」の通合にある久陷を除 くためと、更には降伏点応力を高める事こよつて、断面 の寸度を溥くして、全体としての值激をやすくする為で あらうと推察される。

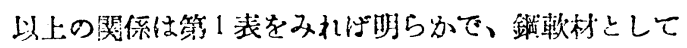
の H-18の状態はないから、2S、3S、52SのOの状態 と63S-T5 又はT6を比べてみればよい。

降伏点が 63S-T5で $1,480 \mathrm{~kg} / \mathrm{cm}^{2}$ てに対して非熱

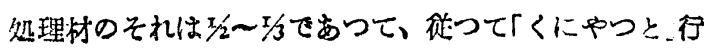

荣 1 四

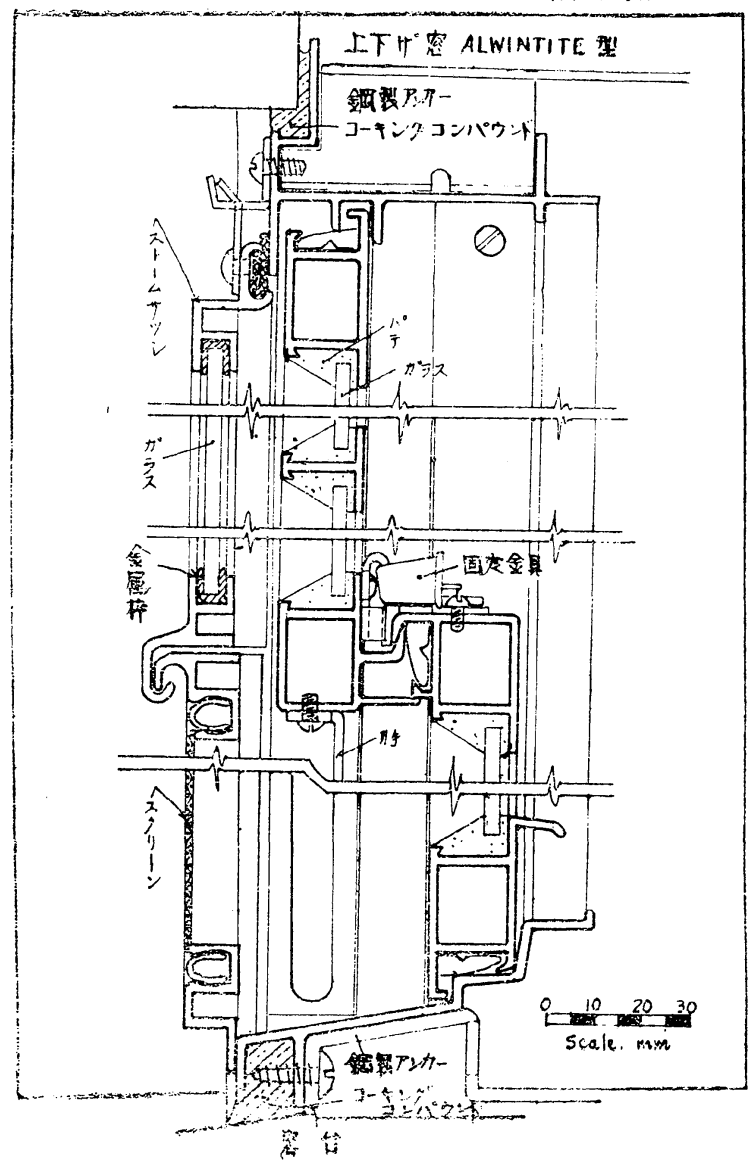

第 1 表

\begin{tabular}{|c|c|c|c|c|c|}
\hline 称 & $\begin{array}{l}\text { 硪断强後 } \\
\mathrm{kg} / \mathrm{cm}^{2}\end{array}$ & $\begin{array}{l}\text { 降 伏点 } \\
\mathrm{kg} / \mathrm{cm}^{2}\end{array}$ & 伸 & 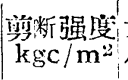 & $\begin{array}{l}\text { プルネ } \\
\text { 几便度 }\end{array}$ \\
\hline $2 \mathrm{~S}-\mathrm{O}$ & $910^{\prime}$ & 350 & 35 & 670 & \\
\hline $2 \mathrm{~S}-\mathrm{H} 18$ & 1,680 & 1,540 & 5 & 910 & \\
\hline $3 \mathrm{~S}-\mathrm{O}$ & 1,120 & 420 & 30 & 770 & \\
\hline $3 \mathrm{~S}-\mathrm{H} 18$ & 2,040 & 1,820 & 4 & 1,120 & ) \\
\hline $52 \mathrm{~S}-\mathrm{O}$ & 1,900 & 840 & 25 & 1,010 & \\
\hline $52 \mathrm{~S}-\mathrm{H} 18$ & 2,880 & 2,530 & 7 & 1,680 & \\
\hline $63 \mathrm{~S}-\mathrm{F}$ & 1,540 & 910 & 20 & 980 & \\
\hline $63 \mathrm{~S}-\mathrm{T} 5$ & 1,900 & 1,480 & 12 & 1,260 & \\
\hline $63 \mathrm{~S}-\mathrm{T} 6$ & $2,4 \in 0$ & 2,170 & 12 & $1,5 \circlearrowleft 0$ & \\
\hline 䩒 銧识 & 3,500 & 2,600 & 25 & & 10 \\
\hline
\end{tabular}

かない為にはそれだけ断而の备片の原さを厚くする必要

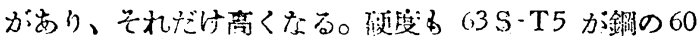

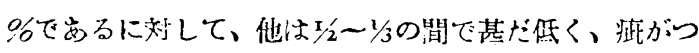
き易い事を分ち。633を伐、ば、面に必要な時さT-6の 状態にして更に硬くする楮も可能である。ここではじめ

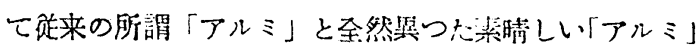
を得て、にこれ!文いいという事になり、少及值が高くな つても使つてみようかといら事にもなろらといらものて

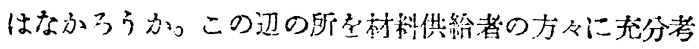

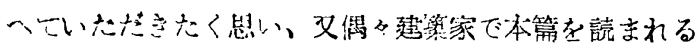

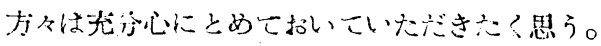

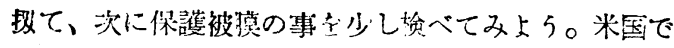
は例外なくメタアクリル酸系透时鉒糊を朋い、組立工場

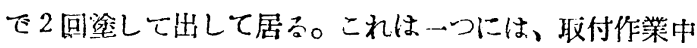
壁の代上作業と工期的に重なり合う為に、壁材料の漟喰 プシスタ、モルタル等のアルカリ性物質が、空枠又は線

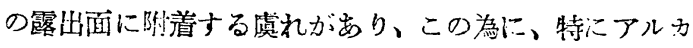
リに対して弱いアルミニウム合鉝か湾色する等を防ぐた めと、もら一つには、パテの馴染みの准とである。

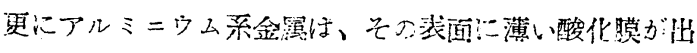
来、これ恔手斩でこすると之等に等く付く欠点方㐫り

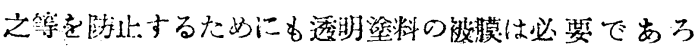

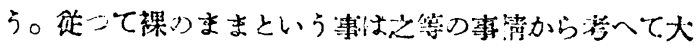
いに反省与る余淮が岁る。

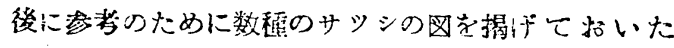

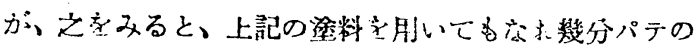

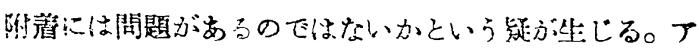

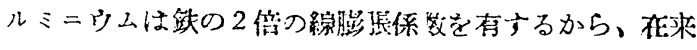
の鍸とガラス $\left(0.118 \times 10^{-4}\right.$ と0.0.0 $\left.010^{-4}\right)$ の組合せに

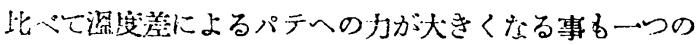

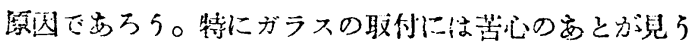
けられるるっが多:。

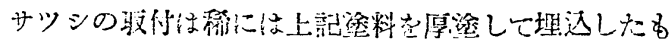

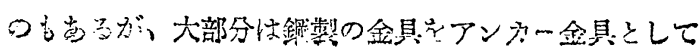




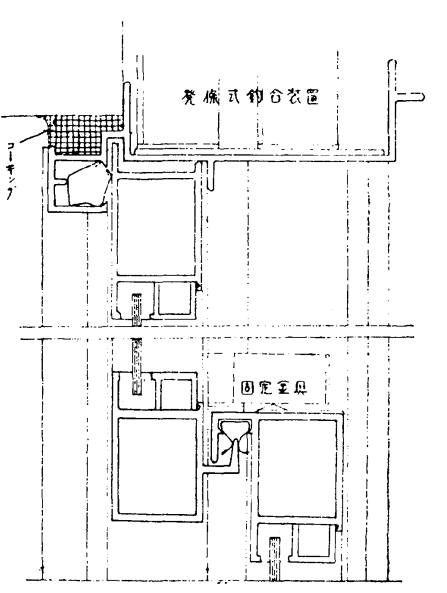

第 3 间
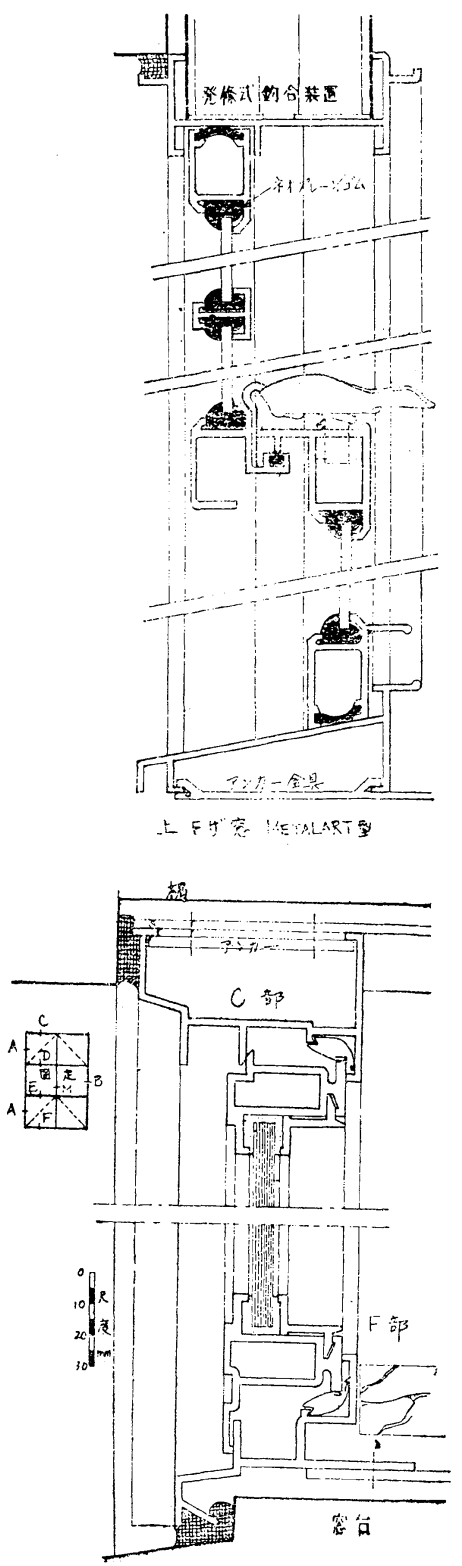

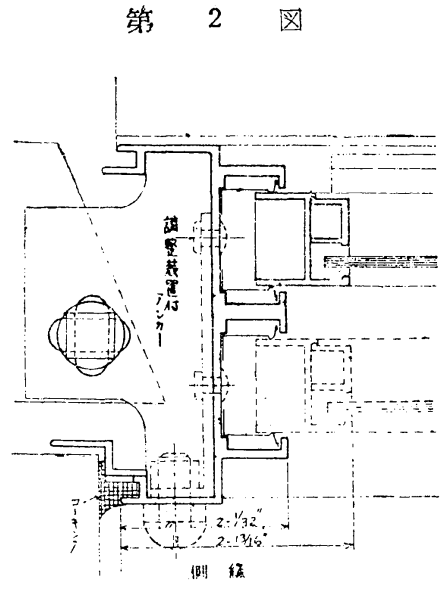

第 4 四

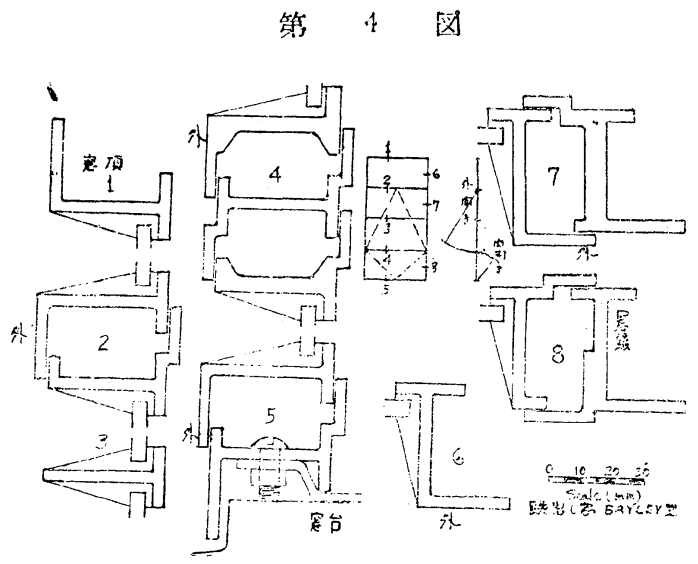

筫 5 図

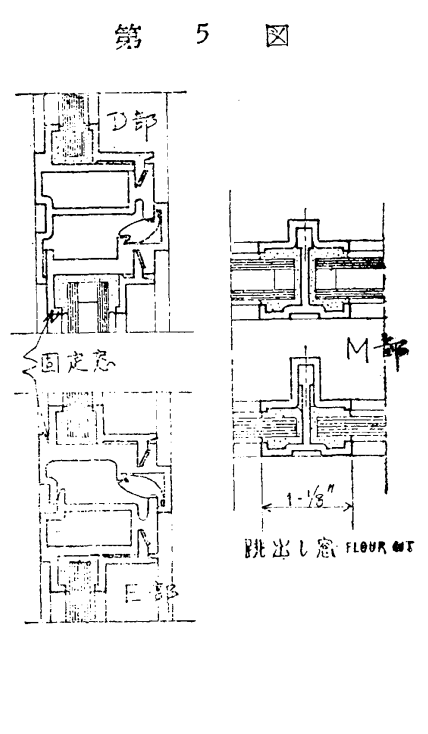

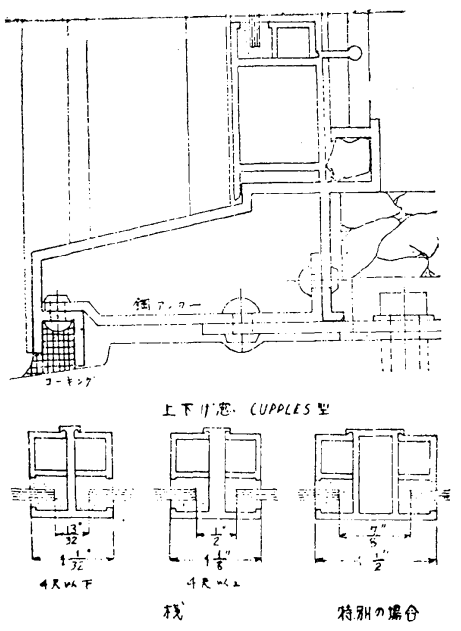

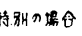

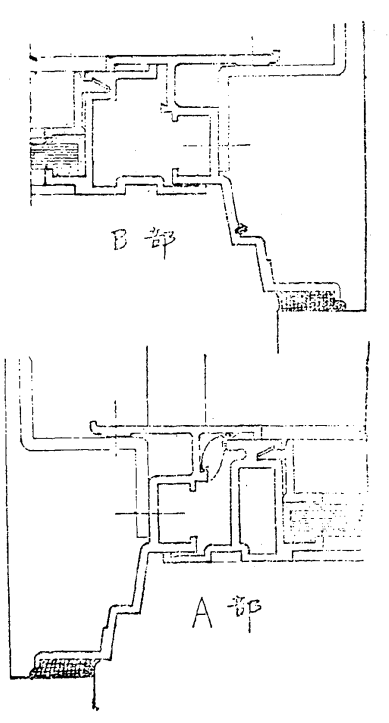


用いている、勿淪之等の金具は不透鋮を用いるのか源則 ではあろうが、值段か高くなるために大部分仿普通堸を

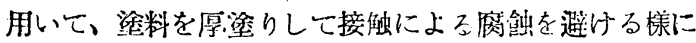
している。
以上が軽合剑サツシの現状に於ける筆者つ不安と、米 国に於ては之をどっ样に解決しているかの概略の展望 でありて、之が茂分でも第界の資料となり、吾国の軽合 金サツシの踺全な発澾に役立てば㤏外の幸である。

\section{軽金属研究会日誌}

\section{2. 15 軽金属䏕究会第 3 回幹事会 於木挽䗆}

明大不田博士、理工研跣田博士、聑大生研加藤助教授

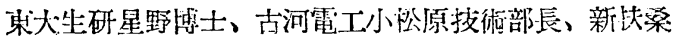
金楀小崎次長、离田アルミ大行取福役、日本軙合金西

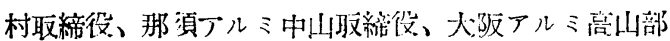
長、日本アルミ小林部長代理、当念櫒临部長、浅里、

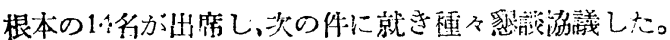

\section{(1) 第 2 回菜演会開催日取の件}

第2 回譂演会は5月16日（金）17日（I）二日間に 亘り大没市に於いて開催する事とし、通俗譜演会 5 月 16日(金) 夜大阪方で商工会議所之其同して開催すここと とした。

\section{（2）丵溑內寄其他に関する件}

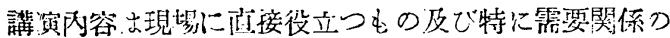
研究報告を多く取入れるように考箅政らこととした。

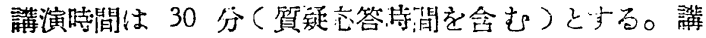

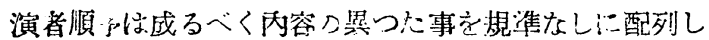
內容的に互にバライテイーを持るせるようにする：特に 講演者が，定より多い場合には1名一報告に制限广る。

\section{（3）工場見学会開催の件}

工場見字会は5月18日（日）閒僬することとし、㽞

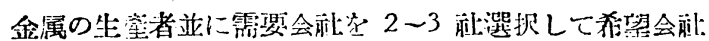
一申込むようにする、全々アルミニウムに孯係のない

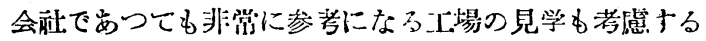
こととした。

\section{（4）世話役の委啒}

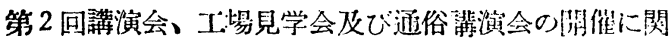

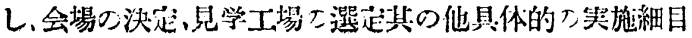

につ、こは地元の関係背に世話役を御願いして一任する こととした。

\section{（5）会誌軽金属の編集方針に関する件}

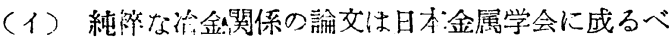

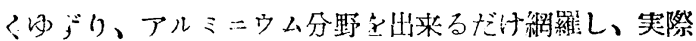

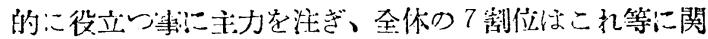

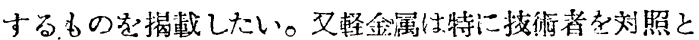
したものとして淮め度い。

（ロ）編集委員会を設けて旬月 1 回宛会合してデイス カツションを行い、文論交は或程度セレクトをしてもよ い势期でないかと思 $万$ との意觉もあつたが、当分は成る ベく全部揭戴することとした。

（ハ）「軽金属」を軽合金刀綜合䊒誌的形体に持つて 行き、これを一册みれば総ての役に立つようにしたい 余り內鹪にセレクトしない方が舆く、序タに內容的に

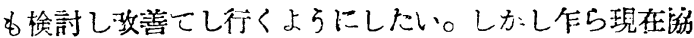

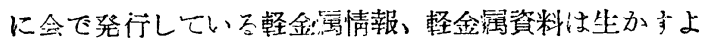
うし当分の䎏三本立てで編集することとした。

（二 最近国際的にアルミニウムがクローズアツプレ て来たので世界の軽金属工業を大きく取、けげた論交も揭 载与ることとした。

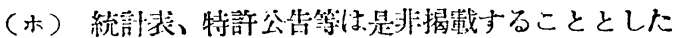

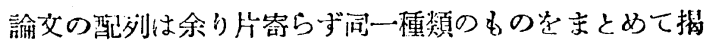
酨することとした。

（へ）今後は原稿の執筆要領を決めて形式の統一化㐋

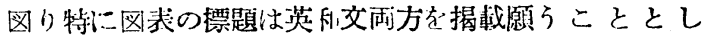
た 